\title{
Nocardia farcinica
}

National Cancer Institute

\section{Source}

National Cancer Institute. Nocardia farcinica. NCI Thesaurus. Code C86615.

A species of aerobic, Gram-positive, rod shaped bacteria assigned to the phylum Actinobacteria. This species is nonmotile, non-spore forming, catalase and urease positive, reduces nitrate, does not produce acid phosphatase, hydrolyzes esculin and testosterone, but not casein, elastin, hypoxanthine, tyrosine, and xanthine, and produces a mycelium and aerial hyphae that fragments into coccoid elements. N. farcinica is found in soil and is a causative agent of nocardiosis. 